\title{
Possibilities of using the dispersed waste of asphalt-concrete plants in the Republic of Buryatia
}

\author{
Nikolay Shestakov ${ }^{1}$, Vyacheslav Tsyrenzhapov ${ }^{2}$, Victoria Rosina ${ }^{3, *}$, and Andrey Komarov ${ }^{3}$ \\ ${ }^{1}$ Moscow State (National Research) University of Civil Engineering, 129337, Yaroslavskoye shosse, \\ 26, Moscow, Russia \\ ${ }^{2}$ East Siberia State University of Technology and Management, 670013, Klyuchevskaya str., 40V, \\ Ulan-Ude, Russia \\ ${ }^{3}$ Irkutsk National Research Technical University, 664074, Lermontova str., 83, Irkutsk, Russia
}

\begin{abstract}
This article considers the possibility of using the dispersed waste of asphalt-concrete plants, namely the dust-entrainment, which is formed during the drying and heating of inert materials and accumulates in special dust-collecting facilities. The material under investigation corresponds to a finely dispersed filler used for the production of asphalt concrete mixtures for a number of features. It has been established that substitution of up to $50 \%$ of the mineral powder with its own dust-entrainment allows obtaining asphalt-concrete mixtures satisfying the requirements for the sharply continental climate.
\end{abstract}

\section{Introduction}

Active improvement of the infrastructure of the Baikal region, opening of new tourist destinations and expansion of the main recreation base of Lake Baikal form high rates of development of the road industry of the Republic of Buryatia. In this connection, work is carried out on the construction, reconstruction and overhaul of the existing network of highways of the region. In 2017, such work is carried out at 23 sites of the federal automobile and 15 sections of the regional roads of the Republic. Constantly increasing rates of construction form a stable shortage in high-quality road construction materials.

Among the materials used in the road industry, the Republic of Buryatia possesses a sufficient quantity of quality stone raw materials, but predominantly silicic and igneous rocks, which are used as large and small fillers. Sedimentary rocks (which are a source of raw materials for the production of the mineral powder necessary for creating asphalt binders) are produced in the region by deposits in the Zaigraevsky district during the production of asphalt-concrete mixtures. Reserves of sedimentary rocks are developed and mastered by two enterprises, namely the Mining Company LLC and the Dolomite JSC, which sell the activated MP-1 mineral powder. During the construction season, there is a shortage of mineral powder, which leads to delaying the construction time and performing work at low temperatures.

\footnotetext{
* Corresponding author: vikt.rozina@yandex.ru
} 
It is known that 60 to 100 tons of mineral powder are applied to the device for covering $1 \mathrm{~km}$ of highways using dense asphalt concrete, depending on the category of the highway, as well as the composition of asphalt and its brand. Meanwhile, in the production of asphaltconcrete mixtures, fine-dispersed wastes are formed and taken away, dust of entrainment. Dust is formed by the operation of the drying drum (at the inlet) and sieves on the mixer (screen) of the hot material elevator [1-3].

\section{Materials and methods}

To determine main properties and establish the possibility of replacing partially or completely the mineral powder with the dust, samples were taken from the cyclone of the asphaltconcrete plant TSC LLC in Ulan-Ude. During the construction season of 2016, the plant produced an asphalt-concrete mixture on granite materials.

Among all the fine waste generated during the operation of an asphalt concrete plant, the most dangerous for workers' health is the free silica ( $\mathrm{SiO} 2)$. According to [4-12], when working with granitic rocks, the greatest amount of dust containing $\mathrm{SiO} 2$ is released, which is the most dangerous for workers' organisms (Table 1).

Table 1. The amount of free silica in the dust, depending on the type of processed rock.

\begin{tabular}{|c|c|c|}
\hline No. & Name of rock & Amount of $\mathrm{SiO}_{2}, \%$ \\
\hline 1 & Granites & $25-65$ \\
\hline 2 & Quartzites & $52-57$ \\
\hline 3 & Sandstones & $35-55$ \\
\hline 4 & Limestones & $3-37$ \\
\hline
\end{tabular}

The chemical composition of the dust was carried out in the Center for Collective Use PROGRESS (East-Siberian State University of Technology and Management) on the scanning electron microscope JSM-6510LV JEOL with the INCA microanalysis system. The data are presented in Table 2.

Table 2. Elemental composition of dust-entrainment.

\begin{tabular}{|c|c|c|c|}
\hline Range & $\begin{array}{c}\text { Content of } \\
\text { elements, } \%\end{array}$ & Range & $\begin{array}{c}\text { Content of } \\
\text { elements, } \%\end{array}$ \\
\hline $\mathrm{O}$ & 51,39 & $\mathrm{Na}$ & 2,18 \\
\hline $\mathrm{Si}$ & 25,56 & $\mathrm{Ca}$ & 2,08 \\
\hline $\mathrm{Fe}$ & 5,53 & $\mathrm{Mg}$ & 1,07 \\
\hline $\mathrm{Al}$ & 7,89 & $\mathrm{Ti}$ & 0,42 \\
\hline $\mathrm{K}$ & 3,50 & $\mathrm{Mn}$ & 0,38 \\
\hline
\end{tabular}

\section{Results and discussion}

According to the results of the given chemical composition, it is established that the predominant compound in the dust is silicon oxide. The processing of such components inside the plant, without removal and disposal of the material is most effective [13-15]. A rational way to solve this problem is to use the dust to prepare asphalt, with the possibility of full or partial replacement of the mineral powder. 
To study this possibility, the main properties of the dust of entrainment of a relatively traditional mineral powder MP-1, used in the Republic of Buryatia - ground dolomite (Table 3).

Table 3. Comparative characteristics of the MP-1 mineral powder and the ABZ dustentrapment.

\begin{tabular}{|c|c|c|c|c|}
\hline No. & Indicator name & $\begin{array}{l}\text { Unit. } \\
\text { amend. }\end{array}$ & Mineral powder MP-1 & Dust \\
\hline 1 & $\begin{array}{c}\text { Grain composition } \\
\text { Smaller } 1.25 \mathrm{~mm} \\
0.315 \\
0.071\end{array}$ & $\begin{array}{c}\% \text { by } \\
\text { weight }\end{array}$ & $\begin{array}{c}100 \\
99.83 \\
81.47\end{array}$ & $\begin{array}{c}100 \\
94.03 \\
33.4\end{array}$ \\
\hline 2 & Average density & $\mathrm{g} / \mathrm{cm}^{3}$ & 2.08 & 1.83 \\
\hline 3 & True density & $\mathrm{g} / \mathrm{cm}^{3}$ & 2,98 & 2.34 \\
\hline 4 & Porosity & $\%$ & 30.1 & 21.8 \\
\hline 5 & Specific surface area & $\mathrm{cm}^{2} / \mathrm{g}$ & 1438.1 & 928.8 \\
\hline 6 & Bituminous capacity & $\%$ & 69.8 & 32.4 \\
\hline
\end{tabular}

As a result of the study on the finely dispersed fillers, it was revealed that the dust of entrainment is represented by larger grains, the main dimension (more than 60\%) lies in the range of $0.315-0.071 \mathrm{~mm}$. The porosity and specific surface of the dust are also inferior to the ground dolomite, which indicates a closed surface structure. According to the granulometric composition, the dust of entrainment does not meet the requirements of the state standard "GOST R 52129-2003"; therefore, the possibility of complete replacement of the mineral powder becomes impossible.

The results of determining the bitumen capacity correspond to well-known data on correlations of grain composition and bituminous capacity of mineral powders. It is known that particles with a bitumen content of less than $0.071 \mathrm{~mm}$ have the greatest bitumen capacity, and as the size of fractions increases, the bitumen capacity decreases according to the parabolic law.

According to the above photographs of the material surface (Figure 1), it is clear that the structure of the fillers under consideration differs significantly. The researched dust has a loose-grained microstructure, whereas ground dolomite is represented by acute-angled elements.

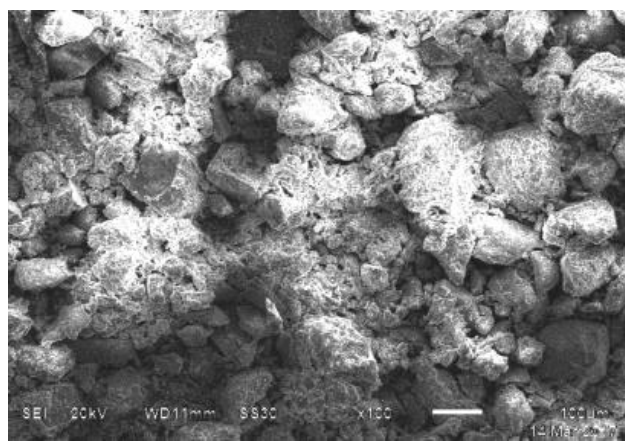

Dust, 100x magnification

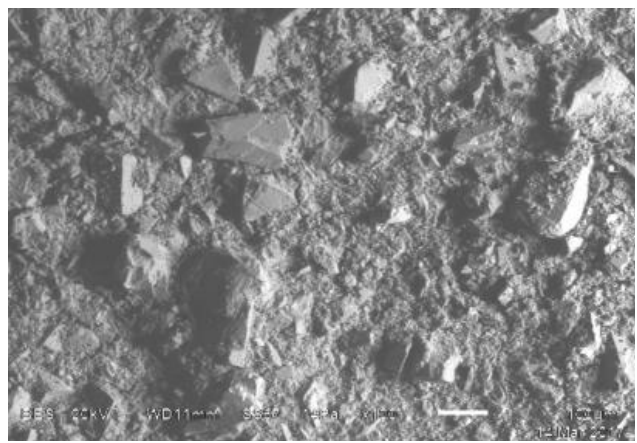

Dolomite, 400x magnification 


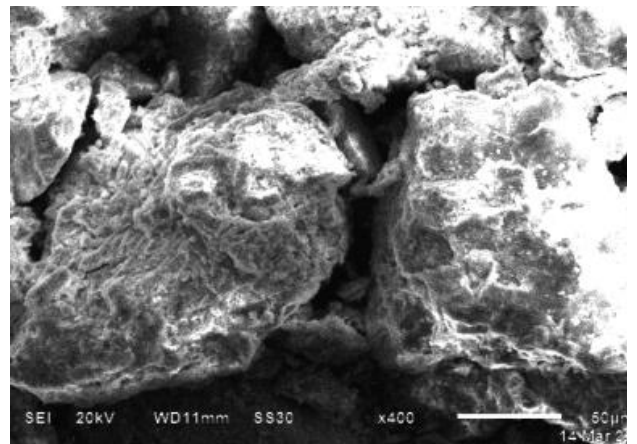

Dust, 400x magnification

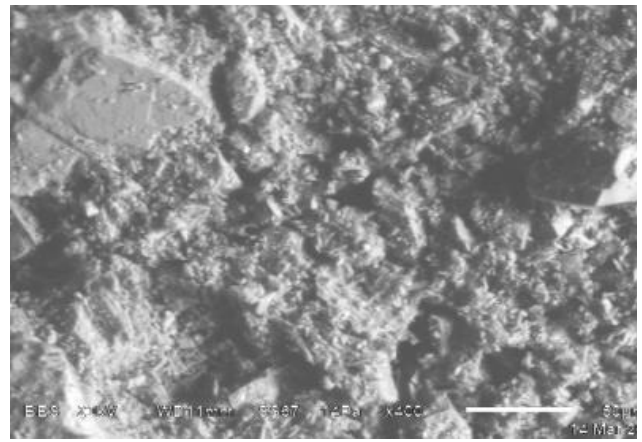

Dolomite, 400x magnification

Fig.1. Microstructure of the researched dust and the mineral powder MP-1 (ground dolomite).

The effect of the researched dust on the properties of asphalt concrete, depending on the quantitative ratio "dust / MP-1 mineral powder" was determined on dense fine-grained asphalt concrete of the "b" type (II mark) (Table 4).

Table 4. Basic properties of asphaltic concrete with replacement of mineral powder with dust.

\begin{tabular}{|c|c|c|c|c|c|c|}
\hline \multirow{2}{*}{ 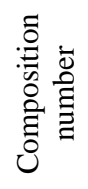 } & \multicolumn{2}{|c|}{ Content of components } & \multirow{2}{*}{$\begin{array}{c}\text { Average } \\
\text { density, g / } \\
\mathrm{cm}^{3}\end{array}$} & \multirow[b]{2}{*}{$\begin{array}{c}\text { Water } \\
\text { saturation, } \\
\%\end{array}$} & \multirow[b]{2}{*}{$\begin{array}{c}\text { Swelling, } \\
\%\end{array}$} & \multirow{2}{*}{$\begin{array}{l}\text { Compressive } \\
\text { strength, } \\
\mathrm{MPa}\end{array}$} \\
\hline & $\begin{array}{c}\text { Mineral } \\
\text { powder } \\
\text { MP-1 }\end{array}$ & Dust & & & & \\
\hline 1 & 100 & 0 & 2,32 & 4,93 & 0,20 & 4,12 \\
\hline 2 & 75 & 25 & 2,32 & 3,45 & 0,21 & 4,75 \\
\hline 3 & 50 & 50 & 2,31 & 3,55 & 0,46 & 3,73 \\
\hline 4 & 25 & 78 & 2,29 & 4,69 & 0,36 & 3,51 \\
\hline 5 & 0 & 100 & 2,22 & 11,06 & 0,99 & 1,60 \\
\hline
\end{tabular}

A necessary condition for the favorable course of the process of structure formation is created, first of all, by full wetting of the mineral material with bitumen. If the wetting at the boundary of the phases of the mineral powder/bitumen is low, this will primarily affect the hydrophysical properties of the asphalt and, as a consequence, its durability. It is known that oxidized bitumens have weak adhesion forces with acid rocks, which includes the dust under consideration. When replacing more than $50 \%$ of the mineral powder with such dust, the water saturation index goes beyond "GOST 9128-2013", which is most likely due to the nature of the material.

The graph of the dependence of the compressive strength at $20^{\circ} \mathrm{C}$ on the amount of dust (Fig. 2) is practically linear and tends to a minimum with increasing amount of dust, which also indicates a decrease in the quality of asphalt concrete when replacing the mineral powder with the dust. However, it should be noted that non-compliance with the requirements of GOST 9128-2013 is observed only when replacing $75 \%$ of mineral powder and more. If the share is cut, the asphalt concrete can withstand the requirements imposed on the upper layers of asphalt concrete pavements. 


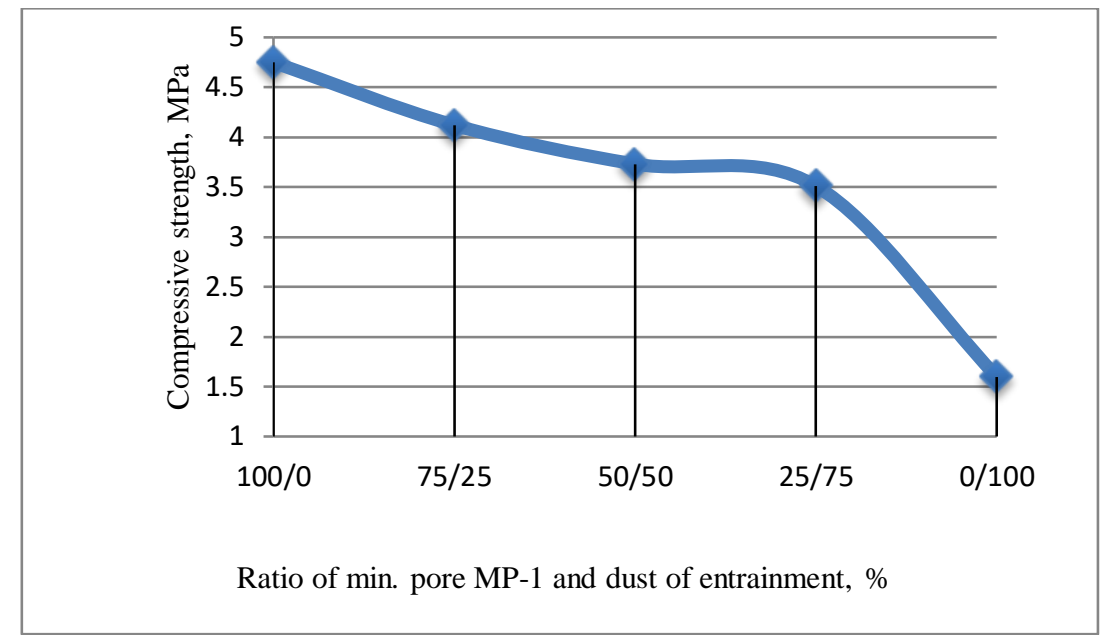

Fig. 2. Change in the strength of asphalt concrete with the increasing amount of dust.

\section{Conclusion}

As a result of the conducted research, it is established that $\mathrm{s}$ it is possible to replace up to $50 \%$ of the mineral powder with own ABZ dust without significantly reducing the quality of the resulting asphalt-concrete mixtures. This transition will save up to 250 rubles per ton of the asphalt-concrete mixture produced and will further reduce the impact of ABZ on the ecological state of the environment.

\section{References}

1. G. E. Saspugaeva, V. S. Kirichenko, Successes of Modern Natural Science, 1-3, 450453 (2015)

2. P. A. Kouzov, Fundamentals of the analysis of the disperse composition of industrial dusts and crushed materials (Chemistry, 1987)

3. Boris L. Muschenko, Scientific Bulletin of the Voronezh State University of Architecture and Civil Engineering, 2, 206-211 (2009)

4. I. I. Leonovich, N. V. Pozhin, Science and Technology, 4 (2010)

5. E. V. Omelchenko, Head of Department, 4-2 (2012)

6. S. I. Dubina, Transport of the Russian Federation. Journal of Science, Practice, Economics, 3(3) (2006)

7. R. A. Musin, Innovation Science, 8-1 (2016)

8. V. P. Yartsev, M. V. Dolzhenkova, N. V. Petrova, Bulletin of TSTU, 4 (2014)

9. V. A. Umnov, GIAB, 5 (1995)

10. N. V. Marhel, L. L. Maslennikova, N. A. Babak, Izvestiya of the Petersburg University of Communications, 2 (35) (2013)

11. K. G. Pugin, V. S. Yushkov, Herald of the Moscow State University, 6 (2014)

12. T. A. Kulagin, O. Kayutin, KrasGAU Herald, 2 (https://cyberleninka.ru/ article/n/tipichnye-problemy-szhiganiya-zhidkih-topliv-v-topkah-malogo-obema-naprimere-raboty-abz, 2007) 
13. V. V. Alekseenko, Yu. V. Saltanova, Bulletin of Science and Education of the NorthWest of Russia, 2 (2016)

14. S. Volnov, L. N. Tretiak, Vestn. OSU, 1 (162), 2014

15. L. A. Nikolaeva, O. N. Burenina, V. E. Kopylov, Privolzhsky scientific bulletin, 121 (52) (2015) 